\title{
IDENTIFIKASI FITUR DASAR LAUT DENGAN MENGGUNAKAN DATA SONAR
}

\author{
Khomsin ${ }^{1}$ and Musdiyana Talif ${ }^{2}$ \\ 1,2 Departemen Teknik Geomatika, FTSLK-ITS, Kampus ITS Sukolilo, Surabaya, 60111, Indonesia \\ e-mail: ${ }^{1}$ khomsin@geodesy.its.ac.id
}

\begin{abstract}
Abstrak
Peta laut (nautical chart) merupakan representasi gambar objek permukaan dan bawah permukaan di wilayah laut dan pesisir yang berisi informasi tentang kedalaman laut, topografi pantai, garis pantai, detil alami dan buatan (pelabuhan, bangunan pantai), pasang surut air laut, arus laut, bahaya navigasi dan fitur dasar laut. Fitur dasar laut (seabed features) merupakan salah satu informasi yang sangat penting yang harus disajikan dalam peta laut untuk keselamatan navigasi di laut. Ada beberapa teknik dan metode yang dapat digunakan untuk mendeteksi fitur dasar laut yaitu dengan menggunakan single beam echosounder, multi beam echosounder, side scan sonar, fotografi dan videografi dasar laut. Penggunaan gelombang suara (sonar) dalam hal pendeteksian fitur dasar laut direkomendasikan oleh International Hydrographic Organizations yang dituangkan dalam Special Publication No. 44 Edisi Kelima Tahun 2008 (IHO, 2008). Penelitian ini bertujuan untuk mendeteksi fitur dasar laut di Perairan Kepulauan Riau dengan menggunakan data Sonar yaitu multibeam echosounder, single beam echosounder dan side scan sonar. Identifikasi dengan kedua data tersebut menunjukkan bahwa fitur dasar di Perairan Kepulauan Riau meliputi batuan dasar $(84,7 \%)$, galian $(3,1 \%)$ dan gelombang pasir $(12,2 \%)$. Objek buatan dasar laut yang teridentifikasi adalah pipa bawah laut dengan total panjang pipa $1636,7 \mathrm{~m}$.
\end{abstract}

Kata Kunci : fitur dasar laut, sonar, multi beam echo sounder, single beam echo sounder, side scan sonar

\begin{abstract}
Nautical charts represent images of surface and subsurface objects in marine and coastal areas containing information on ocean depths, coastal topography, coastlines, natural and artificial details (harbors, coastal structures), sea tides, ocean currents, navigation hazards and seabed features. Seafloor features are one of the most important information that should be presented in nautical chart for marine navigation safety. There are several techniques and methods that can be used to detect seabed features by using multi beam echo sounder, single beam echo sounder, side scan sonar, seabed photography and videography. The use of sound waves (sonar) in terms of seabed features detection is recommended by the International Hydrographic Organizations as outlined in Special Publication No. 44 Fifth Edition of the Year 2008 (IHO, 2008). This study aims to detect the seabed features in the Riau Islands Water by using Sonar data: single beam echo sounder and side scan sonar. Identification with both data indicates that the seabed features in the Riau Islands waters comprise bedrock (84.7\%), excavation (3.1\%) and sand ripples (12.2\%). The identified seabed manmade object is an undersea pipeline with a total length of $1636.7 \mathrm{~m}$.
\end{abstract}

Keywords : seabed features, sonar, single beam echo sounder, side scan sonar

\section{PENDAHULUAN}

Fitur dasar laut merupakan bagian dari panorama permukaan dasar laut atau morfologi dengan gambaran sebagaimana yang ada di daratan, seperti kenampakkan dari pegunungan, gunung api, lereng, dataran, lembah, parit, dan channel. Bentuk morfologi tersebut, umumnya berkaitan dengan proses-proses geologi dalam pembentukan dan perkembangannya baik secara individual maupun secara berkelompok.
Berdasarkan peta batimetri Indonesia, pola batimetri yang berkembang memperlihatkan morfologi dasar lautnya mengikuti garis pantai dan pola hasil tektonik (Salahudin, 2010).

Data fitur dasar laut dibutuhkan untuk kegiatan konstruksi lepas pantai seperti pembuatan anjungan, pemasangan pipa bawah laut, dan pemasangan kabel. Sebelum melaksanakan kegiatan tersebut diperlukan proses identifikasi 
fitur dasar laut untuk menganalisa resiko dan menentukan tempat yang aman dalam pemasangannya. Selain kegiatan konstruksi lepas pantai, fitur dasar laut juga dijadikan pertimbangan untuk menentukan jalur pelayaran yang aman. Oleh karena itu fitur dasar laut baik yang terbentuk secara alami karena proses alam ataupun buatan yang terbentuk karena benda buatan manusia yang masuk ke dasar perairan, dapat digambarkan dalam bentuk peta dan diklasifikasikan agar posisi dan informasi dapat diketahui.

Metode akustik saat ini banyak digunakan untuk mendeteksi keberadaan objek bawah laut. Sothall dan Nowacek (2011) menyatakan sistem akustik sangat efektif untuk mengeksplorasi lingkungan bawah laut. Prinsip dasar dari sonar adalah menggunakan gelombang suara untuk mendeteksi objek khususnya di dasar laut (Hansen, 2011). Teknologi akustik yang sangat berperan dalam survei hidrografi adalah multi beam sonar (McGonigle, 2010).

Menurut Calder dan Mayer (2003), multi beam echo sounders (MBES) saat ini merupakan cara terbaik untuk menentukan bathimetri dasar laut dengan area yang sangat luas dengan akurasi yang tinggi. Oleh karena itu MBES merupakan alat yang standar untuk survei hidrografi dan dapat digunakan untuk studi geologi, eksplorasi mineral, dan investigasi scientifik deformasi kerak bumi. Peningkatan data akan naik secara signifikan dalam hal delineasi morfologi dasar laut. Akan tetapi MBES mempunyai kelemahan dalam hal pemrosesan data dengan volume data yang sangat besar.

Instrumen penunjang berikutnya untuk melengkapi data hasil pengukuran adalah side scan sonar (SSS). Hasil pengolahan data side scan sonar adalah berupa citra sehingga dapat melengkapi data multi beam echo sounder untuk melakukan interpretasi objek atau fitur dasar laut. Selain side scan sonar diperlukan juga data single beam echo sounder sebagai data penunjang untuk memvalidasi data kedalaman yang dihasilkan oleh multi beam echo sounder. Hal ini dikarenakan multi beam echo sounder dapat melakukan perekaman data dengan cakupan luas dan memiliki keakuratan yang baik dalam positioning tetapi tidak dengan kedalaman, sedangkan single beam echo sounder memiliki keakuratan yang baik dalam postioning dan juga kedalaman.

\section{METODE}

Data bathimetri yang digunakan pada penelitian ini adalah data multi beam echo sounder Edgetech 6205, single seam echo sounder Odom Echotrack MKII, side scan sonar Edgetech 6205 dan positioning menggunakan DGPS Veripos $L D 4$ yang bereferensi pada datum WGS 1984. Area survey memiliki panjang sekitar 3000 meter dan lebar 250 meter. Data-data tersebut dikalibrasi dengan gerakan kapal pitch, roll, yaw (heading) dan latency. Selanjutnya data dikoreksi dari pembersihan spike (loncatan nilai kedalaman), pasang surut yang digunakan untuk mereduksi kedalaman dan kecepatan suara dalam air. Data terkoreksi selanjutnya di gridding dengan menggunakan software Qinsy 8.1 dan selanjutnya diplotting pada AutoCAD.

\section{HASIL DAN PEMBAHASAN}

Peta batimetri lokasi penelitian mempunyai rentang kedalaman mulai kedalaman paling dangkal yaitu $-1,5$ meter dan untuk kedalaman yang paling dalam adalah -22 meter. Kondisi dasar laut area survei memiliki topografi bergelombang atau berbukit dikarenakan batuan dasar laut yang dominan (Gambar 1).

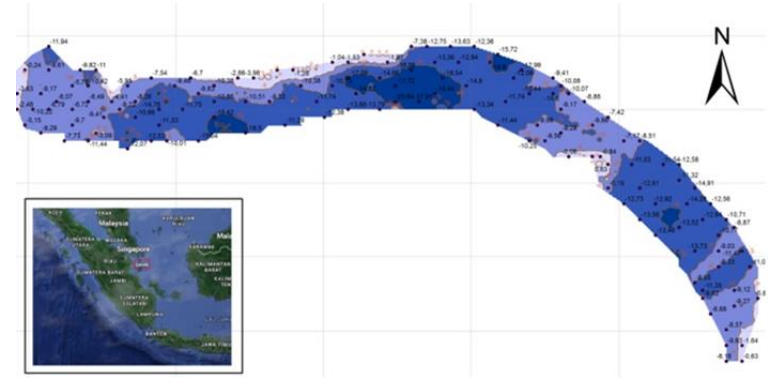

Gambar 1. Peta Batimetri di Perairan Kepulauan Riau

Citra permukaan dasar laut dari side scan sonar EdgeTech 6205 setelah dikoreksi dengan jarak miring (slant range correction) dan TVG (Time Varied Gain), hasil mozaik citra dasar perairan (Gambar 2). 


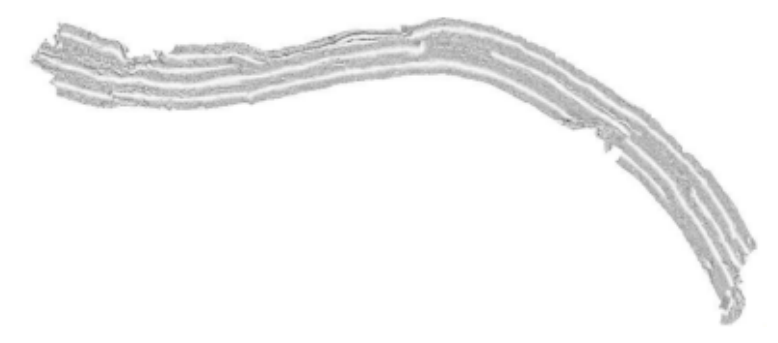

Gambar 2. Hasil Mosaic Citra Side Scan Sonar

Fitur dasar laut yang merupakan gabungan dari side scan sonar dan multi beam echo sounder dapat dilihat pada Gambar 3.

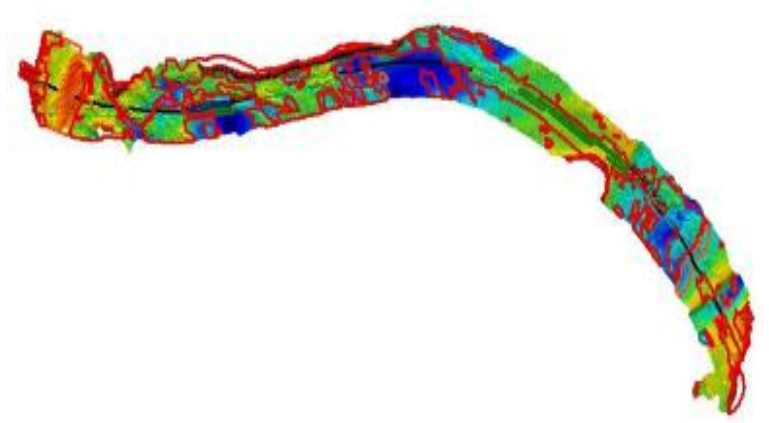

Gambar 3. Tampilan Fitur Dasar Laut Di Lokasi Penelitian

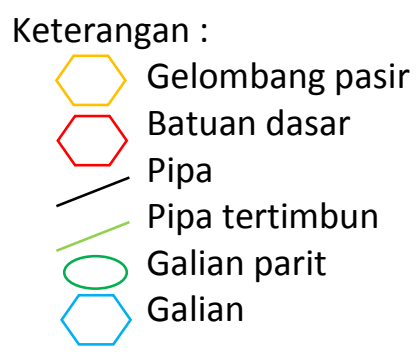

Pada citra jalur survei ML-I terlihat beberapa anomali yang menampilkan tekstur yang tidak rata dan variasi pola yang terbentuk sehingga mengindikasikan adanya beberapa fitur dasar laut yang ditemukan, diantaranya:

- Pasir bergelombang ditunjukkan dengan area kotak berwarna orange memperlihatkan pola bergelombang yang rapi dengan tekstur halus serta mempunyai reflektor lemah.

- Batuan dasar pada area yang diberi tanda lingkaran berwarna merah ditandai dengan gambaran hasil citra yang terlihat mempunyai tekstur kasar dengan reflektor yang kuat dan membentuk pola berkelompok.

- Pipa ditandai dengan garis hitam yang terlihat seperti garis lurus memanjang menghasilkan bayangan yang memiliki dimensi serta reflektor yang kuat dan mempunyai jarak dengan bayangannya yang disebut dengan free span.

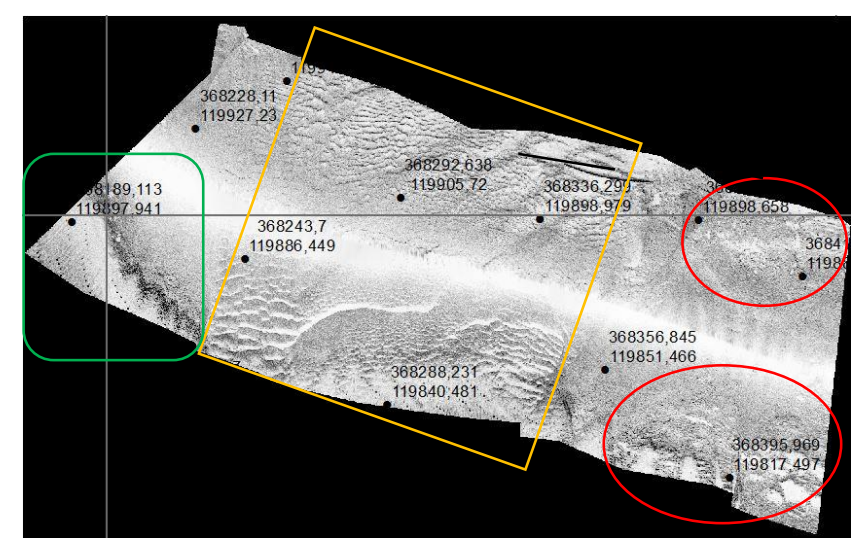

Gambar 4. Jalur Survei ML-1 Terdapat Fitur Gelombang pasir dan Batuan dasar

Jalur survei ML-1 memiliki gangguan sinyal (noise) sehingga terdapat bagian citra yang berbentuk hitam dengan garis-garis diagonal dan transparan yang terdapat pada pojok kiri citra. Noise bisa disebabkan oleh beberapa faktor, salah satu nya adalah manuver kapal, gangguan gelombang dan lainnya.

Hasil verifikasi jalur survei ML-1 pada peta seabed features hasil akuisisi single beam echo sounder ditemukan beberapa fitur, yaitu gelombang pasir, batuan dasar dan pipa. Setelah dilakukan mozaik citra ditemukan fitur yang sama di jalur yang berdekatan. Sehingga dapat digabungkan untuk dimasukkan dalam klasifikasi. Fitur gelombang pasir yang berada di radius jalur survei ML-1 diberikan ID SW 6 dengan area fitur berwarna putih, batuan dasar diberikan ID BR 50 pada area berwarna merah dan pipa diberikan ID PL 5 dengan tanda garis lurus berwarna hitam.

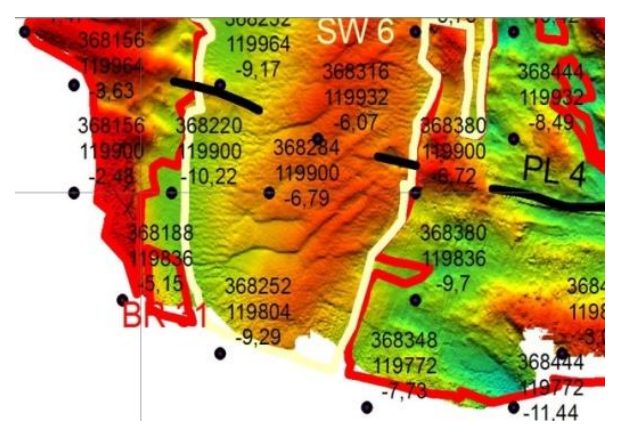

Gambar 5. Verifikasi Jalur ML-1 
Kedalaman fitur gelombang pasir ID SW 6 berada di range antara $-4,99$ dan $-10,48$ meter gambaran tekstur pada fitur tidak jauh berbeda dengan citra side scan sonar yang memiliki pola bergelombang akibat arus air laut. Letak koordinat fitur berada di posisi (368312,942367); (119962,101226) dengan luasan $42378,73 \mathrm{~m}^{2}$.

Fitur batuan dasar mempunyai tekstur yang kasar dengan perbedaan kedalaman yang lebih rendah dibandingkan dengan area sekitar. Kedalaman ID BR 50 ini berada di rentang antara $-3,05$ sampai $-9,7$ meter dengan bentuk topografi yang tidak rata atau berbukit. Letak koordinat fitur berada di posisi $(368518,246829)$; $(119897,459581)$ dengan luasan $61379,489 \mathrm{~m}^{2}$.

Untuk verifikasi pipa jalur ML-1 dikarenakan grid jarak titik batimetri tidak berdekatan maka sulit untuk mengidentifikasi pipa menggunakan titik multi beam echo sounder pada peta batimetri. Untuk itu digunakan single beam echo sounder dalam melakukan verifikasi sesuai dengan letak koordinat (358268;199542) dengan rentang kedalaman -9,3 sampai -10 meter dengan panjang pipa 25,940 meter.

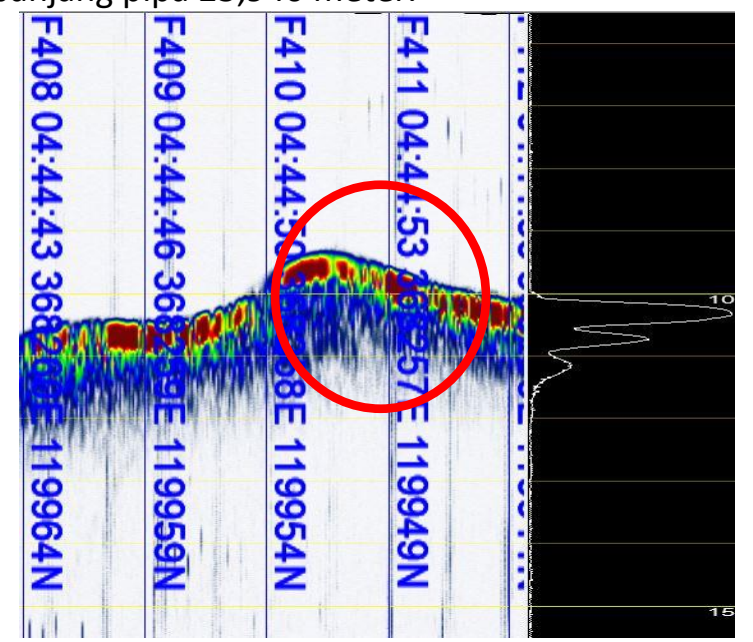

Gambar 6. Verifikasi Pipa dengan profil melintang instrumen Singlebeam Echosounder

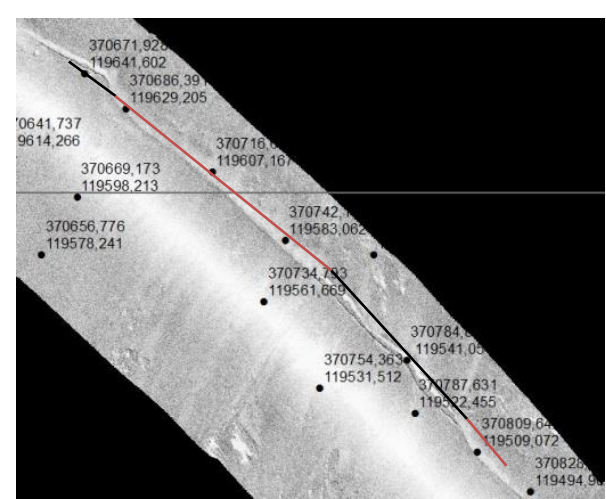

Gambar 7. Jalur Survei ML-4 Terlihat Fitur Pipa dan Pipa Tertimbun

Berbeda dengan jalur-jalur survei sebelumnya dari hasil deteksi fitur dasar laut. Pada jalur survei ML-4 memperlihatkan sebuah fitur dengan garis memanjang dan membentang yang telah ditandai dengan garis hitam. Fitur-fitur tersebut adalah pipa ditandai dengan garis berwarna hitam yang terlihat dengan pola seperti garis berbentuk gundukan memanjang. Dapat diidentifikasi juga dari bayangan yang dihasilkan dari reflektor yang kuat dan mempunyai jarak antara objek yang berwarna hitam, yang diindikasikan sebagai free span akibat tinggi pipa yang menggantung sehingga membentuk bayangan dan adanya jarak dengan objek. Pipa tertimbun yang ditandai dengan garis berwarna coklat, bentukan atau pola yang dihasilkan sama dengan pipa akan tetapi pipa tertimbun tidak mempunyai bayangan seperti pipa yang terdeteksi dari instrumen side scan sonar pada umumnya. Hal ini dikarenakan pipa tertutupi ole sedimen yang ada di dasar laut.

Terdapat indikasi pipa dan pipa tertimbun pada jalur survei ML-4 dengan ID masing-masing PL 9 dan 11 pada peta diberikan tanda garis berwarna hitam serta BP 1 dan 2 yang memiliki tanda garis berwarna kuning. Pola panjang membentang dan seperti gundukan merupakan beberapa karakteristik dan ciri khas pipa pada semua instrumen. 


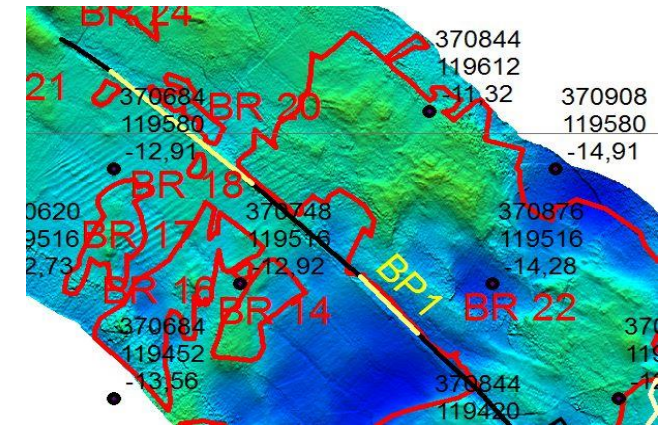

Gambar 8. Verifikasi Jalur Survei ML-4

Berdasarkan dengan akuisisi multi beam echo sounder terdapat pipa di jalur yang sama dengan hasil interpretasi pada citra side scan sonar. Posisi dan panjang pipa dapat dilihat pada tabel analisa fitur pipa dan pipa tertimbun. Tidak ada perbedaan yang mencolok dari kedua fitur ini, jika dilihat dari tampilan seabed features.

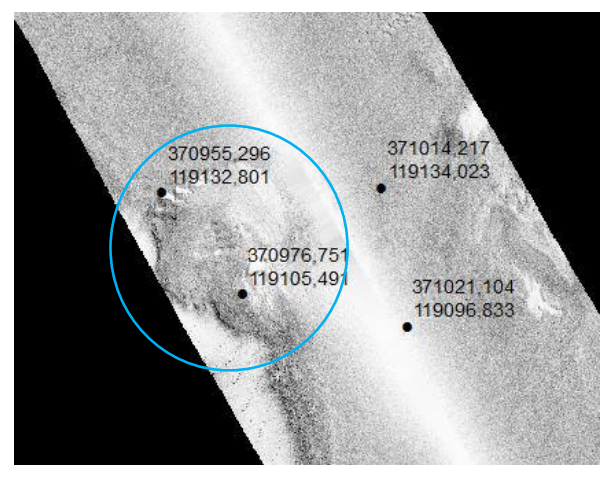

Gambar 9. Jalur Survei ML-1A Terlihat Fitur Galian

Jalur survei ML-1A ini memperlihatkan sebuah fitur dasar laut berbentuk melingkar dengan bentuk pola seperti kerukan. Fitur dasar laut tersebut biasa disebut dengan galian yang diberi tanda lingkaran berwarna biru muda. Setelah melakukan interpretasi awal terhadap jalur survei maka dilakukan proses mosaic untuk melihat keseluruhan tampilan citra sehingga fitur yang memiliki karakteristik dan pola yang sama dapat langsung diklasifikasikan untuk membuat Peta Klasifikasi Fitur Dasar Laut Perairan Kepulauan Riau.
Verifikasi fitur terakhir berada di jalur ML-1A dengan ID DR 1 ditandai dengan area berbentuk lingkaran berwarna biru muda memiliki perbedaan kedalaman dengan area sekitar fitur. Posisi dari fitur ini terletak pada (370971,489957); (119117,603106) dan luasan 1312,337 $\mathrm{m}^{2}$.

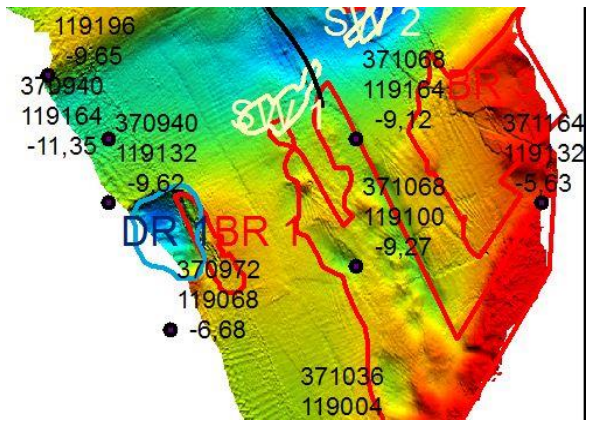

Gambar 10. Verifikasi Jalur ML-1A

Untuk melihat profil kedalaman maka dibutuhkan verifikasi dari hasil akuisisi single beam echo sounder sehingga dapat terlihat perbedaan kedalaman pada fitur galian dengan ID DR 1. Dari Gambar 11 memperlihatkan bentuk profil fitur galian dengan range kedalaman yaitu antara -11 hingga - 15 meter. Akan tetapi untuk area disekitar galian yang berbentuk datar kedalamannya mencapai -9 meter dan tidak tercantum dalam gambar profil single beam echo sounder.

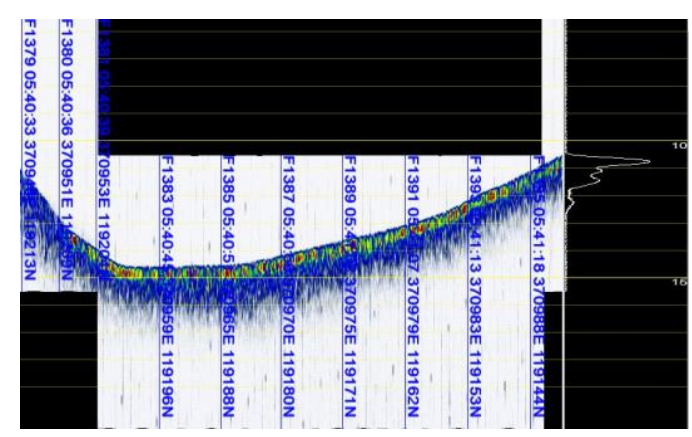

Gambar 11. Verifikasi Fitur Galian

\section{KESIMPULAN}

Identifikasi fitur dasar laut di Perairan Kepulauan Riau dengan multi beam echo sounder, side scan sonar dan single seam scho sounder menunjukkan bahwa batuan dasar 84,7\%), galian (3,1\%) dan gelombang pasir $(12,2 \%)$. Objek buatan dasar laut yang teridentifikasi di Perairan Kepulauan Riau adalah pipa bawah laut dengan total panjang pipa adalah $1636,7 \mathrm{~m}$. Selanjutnya untuk mendapatkan hasil yang optimal perlu dilakukan verifikasi hasil dengan menggunakan grab sampler untuk memperoleh sedimen dasar laut. 


\section{UCAPAN TERIMA KASIH}

Penulis mengucapkan terimakasih sebesar-besarnya kepada PT. PAGEO UTAMA yang telah menyediakan data-data, hardware dan software yang diperlukan dalam penelitian ini.

\section{DAFTAR PUSTAKA}

Salahudin, M. W (2010).P3GL. Dipetik Maret 8, 2016, dari $M G I \quad$ ESDM: http://www.mgi.esdm.go.id/content/morfologidasar-laut-indonesia

Sothall, B., \& Nowacek, D. (2011). Acoustics in Marine Ecology. Innovation in Technology Expands the Use of Sound in Ocean Science, 1-3.

Hansen, R. (2011). Instroduction to Synthetic Aperture Sonar, in Sonar Systems. Dalam Fitrs Edition (hal. 1-25). Croatia: InTech.

McGonigle C, G. J. (2010). Detection of Deep Water Benthic Macroalgae Using Image-based Classification Techniques on Multibeam Backscatter at Cashes Ledge, Gulf of Marine. Estuarine, Coastal and Shelf Science, 87-101

Calder, B. R., \& Mayer, L. A. (2003). Automatic processing of high-rate, high-density multibeam echosounder data. Geochemistry, Geophysycs, Geosystem , Issue 6. 